\title{
Partition of rainfall variation effect on crop productivity into amount and distribution effects
}

\author{
Mohammed Jlibene 1* $^{*}$ \\ Independent and previously-researcher at INRA Maroc, Morocco
}

\begin{abstract}
Rainfall is the most influential factor of rainfed agricultural production in semi-arid Mediterranean and Sub-Saharan environments. While effects of rainfall amount and distribution are confounded, their partition will help developing strategies to manage green water in these environments. A series of 39 years of country average cereal yield and rainfall data was used (1981-2019). Cumulated rainfall over months of November, Rainfall of the month of January, February and March of Central location of Marchouch $\left(33.5613^{\circ} \mathrm{N}, 6.6919^{\circ} \mathrm{W}\right.$ ) taken as a representative of agricultural land, were used because of high correlations with yield. Regression of cereal yields on rainfall showed scattered points below a top frontier line representing highest water productivity (yield/rainfall), accounting for effect of amount independent from distribution. Regression of all 39 yields on rainfall accounts for both confounded effects of amount and distribution. Difference indicates effectofdistribution of rainfall. Cumulated rainfall over the 4 months, varied from $64.20 \mathrm{~mm}$ to $447 \mathrm{~mm}$ with an average of $219 \mathrm{~mm}$. Yields ranged from $3.59 \mathrm{q} / \mathrm{ha}$ to $22.88 \mathrm{q} / \mathrm{ha}$ with an average of $12.29 \mathrm{q} / \mathrm{ha}$. Top water productivity indicating effect of amount was $3.98 \mathrm{~kg} / \mathrm{mm}$. Distribution of rainfall reduced actual yields by $13 \%$ to $50 \%$ depending on season and cereal crop. The model can be adapted to rainfed crops in semiarid environments.
\end{abstract}

\section{Introduction}

Rainfall influences cereal yields in rainfed Mediterranean arid environments. The total rainfall over the months of September until may correlated positively with cereal yield in Morocco $(\mathrm{r}=0.70)$, using cereal yield and Marchouch rainfall data of a series of 39 years, Whenever there is an increase or a decrease in rainfall, cereal yields fallow the same trend, for the last 39 cropping seasons, with 2 exceptions of increased rainfall fallowed by decreased yield and 5 exceptions of decreased rainfall amount fallowed by increased yield. Increased yield fallowing decreased rainfall may have more likely resulted from a favorable distribution within the season.

\footnotetext{
*Corresponding author: jlibene.mohammed@gmail.com
} 
Water productivity may be used as an indicator to appreciate the effect of total rainfall on yield, including both amount and distribution [1, 2]. The effect of rainfall distribution has not, up to date at least to our knowledge, been isolated. Breaking down those effects will help setting strategies for rainfall management in rainfed crop production systems in drought prone environments.

The objective of this communication is to present a method of partitioning confounded effects on yield into single effects due to amount and to distribution.

\section{Method}

Regressing yield on rainfall for a long data series shows scattered points below a frontier line which represents top yields for each level of rainfall amount, or high water productivity (Figure-1). The frontier regression line is expected to show effect of amount of rainfall under optimal distribution, measured by the coefficient of regression.

Regressing yield on rainfall for the whole series is expected to show effects of both amount and distribution confounded.

Difference between the two will shows effect of distribution, independent from amount of rainfall. Since distribution is intended to be a deviation from optimal distribution, its effect is expected to be negative, and effect of the amount of rainfall to be positive. If the two regression lines are parallel, effect of distribution is the difference between the intercept.

The effect of distribution is an average effect. Deviation of individual yield from frontier regression line may involve other factors like sowing date, temperature, diseases or insects.

Moroccan average yield of cereal including bread wheat, durum wheat and barley and rainfall of Marchouch location for the last four decades (1981-2019) have been used in this study [3]. Since country rainfall average data was not available, we used data of the INRA experimental of Marchouch, located in the center of Moroccan agricultural lands $\left(33.5613^{\circ}\right.$ $\left.\mathrm{N}, 6.6919^{\circ} \mathrm{W}\right)$. This location happens to correlate with most agricultural locations in Morocco (Tadesse, personal communication., 2020) and therefore was used as a representative of total agricultural lands of Morocco.To improve the correlation between rainfall and yield, the months of November, January, February and March were used because of their best correlations to yield. The correlation was improved to 0.78 . 


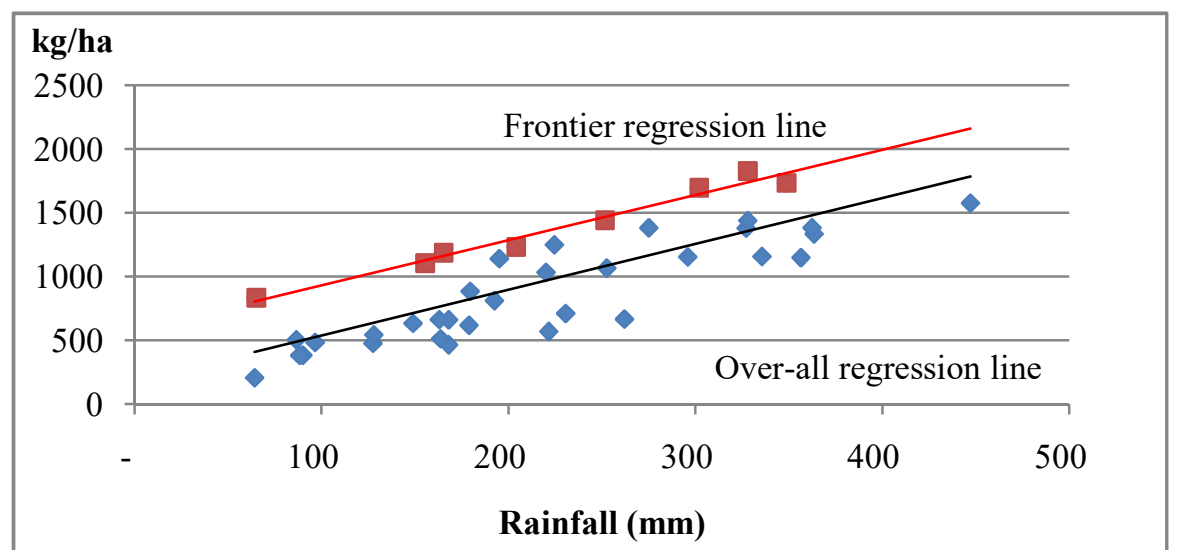

Fig.1: Regression of yield on rainfall. The frontier regression line in top indicates situations of well distributed rainfall. Slope represents amount effect on yield, and difference among intercepts represents distribution effect.

Regression parameters for cereals in general, and for individual species, bread wheat, durum wheat and barley, are in results and discussion section below.

\section{Results and discussion}

Considering the total rainfall of the four months during the last four decades, rainfall, yield and water productivity, were highly variable, as expected, 7-folds, 6-folds, and 5-folds respectively. Both variations in total amount of rainfall and its distribution account for $65 \%$ yield and water productivity variations.

Table 1: Statistics (minimum, maximum, average and range) of rainfall, cereal yield and cereal water productivity. Data from Morocco, 39 seasons. Rainfall of INRA location of Marchouch representing average rainfall of agricultural lands of Morocco. Yields are country average, official statistics

(ONICL, 2020).

\begin{tabular}{|l|c|c|c|}
\hline Statistics & Rainfall $(\mathrm{mm})$ & Yield $(\mathrm{kg} / \mathrm{ha})$ & Water productivity $(\mathrm{kg} / \mathrm{mm})$ \\
\hline Minimum & 64.2 & 359 & 3.26 \\
\hline Average & 219 & 1229 & 6.03 \\
\hline Maximum & 447 & 2288 & 16.73 \\
\hline Range & $1: 7$ & $1: 6$ & $1: 5$ \\
\hline
\end{tabular}




\section{Effects of amount and distribution by species}

According to this model, the effect of amount of rainfall is positive and rainfall dependent, and is measured by the coefficient of regression indicating water productivity, and effect of distribution is negative and independent from rainfall amount.

Table 2: Effects of amount and distribution of rainfall on major cereal crops in Morocco.

\begin{tabular}{|l|l|l|l|}
\hline \multirow{2}{*}{ Species } & Amount & Amount \& distribution & Distribution* \\
\hline Bread Wheat & $5.03 \mathrm{x}+968 ; \mathrm{R}^{2}=0.96$ & $4.19 \mathrm{x}+544 ; \mathrm{R}^{2}=0,56$ & $0.84 \mathrm{x}-424$ \\
\hline Durum Wheat & $4.86 \mathrm{x}+930 ; \mathrm{R}^{2}=0.97$ & $4.24 \mathrm{x}+436 ; \mathrm{R}^{2}=0.57$ & $-0.62 \mathrm{x}-494$ \\
\hline & $3.54 \mathrm{x}+578 ; \mathrm{R}^{2}=0.97$ & $3.6 \mathrm{x}+178 ; \mathrm{R}^{2}=0.65$ & $0.06 \mathrm{x}-400$ \\
\hline Barley & $4.62 \mathrm{x}+781 ; \mathrm{R}^{2}=0.99$ & $3.98 \mathrm{x}+357 ; \mathrm{R}^{2}=0.60$ & $-0.64 \mathrm{x}-424$ \\
\hline
\end{tabular}

*Non-significant coefficients of regression, considered as estimates of 0 .

Bread wheat showed highest water productivity $(5.03 \mathrm{~kg} / \mathrm{mm})$ followed by durum $(4.86$ $\mathrm{kg} / \mathrm{mm})$ and barley $(3.54 \mathrm{~kg} / \mathrm{mm})$. Durum wheat was most affected by rainfall distribution, followed by bread wheat and barley.

Table3: Effects of rainfall distribution on cereal crops productivities estimated at minimum, average and maximum rainfall to indicate variation.

\begin{tabular}{|c|c|c|c|c|c|c|}
\hline & \multicolumn{3}{|c|}{ Yield by level of rainfall } & \multicolumn{3}{|c|}{ Yield loss $(\%)$ due to distribution, at } \\
\hline Species & $\begin{array}{c}\text { Minimum } \\
64.2 \mathrm{~mm}\end{array}$ & $\begin{array}{l}\text { Average } \\
219 \mathrm{~mm}\end{array}$ & $\begin{array}{l}\text { Maximum } \\
447 \mathrm{~mm}\end{array}$ & $\begin{array}{c}\text { Minimum } \\
64.2 \mathrm{~mm}\end{array}$ & $\begin{array}{l}\text { Average } \\
219 \mathrm{~mm}\end{array}$ & $\begin{array}{c}\text { Maximum } \\
447 \mathrm{~mm}\end{array}$ \\
\hline Bread Wheat & 1291 & 2070 & 3216 & $-33 \%$ & $-21 \%$ & $-13 \%$ \\
\hline Durum Wheat & 1242 & 1994 & 3102 & $-40 \%$ & $-25 \%$ & $-16 \%$ \\
\hline Barley & 805 & 1353 & 2160 & $-50 \%$ & $-30 \%$ & $-19 \%$ \\
\hline All Cereals & 1078 & 1793 & 2846 & $-39 \%$ & $-24 \%$ & $-15 \%$ \\
\hline
\end{tabular}


The potential of wheat water productivity in semi-arid environments of Morocco was estimated at $22 \mathrm{~kg} / \mathrm{mm}$ of rainfall consumed during the crop cycle [1]. The cereal productivity country wise is way below this figure, indicating the potential for improvement.

Average yield loss from erratic distribution of rainfall ranged from $13 \%$ to $50 \%$, depending on the species and level of rainfall. It is quite high, which warrant search for efficient rainfall water management measures.

Among measures that can be adopted, the fallow system allow to transfer water from season to other, vegetative covering of the soil and mulching which reduces evaporation losses, appropriate cultural practices to improve water productivity, supplemental irrigation... Water productivity was improved by adopting these measures [2] which are expected to mitigate the effect of erratic distribution as well.

The rainfall effect partitioning method can be adapted to other rainfed crops in rainfall dependent and drought prone environments.

\section{References}

1. M. Jlibene. Options génétiques d'adaptation du blé tender au changement climatique ; Variétés à résistances multiples : sécheresse, cécidomyie, septoriose, rouilles brune et jaune. Edition INRA. (2009).

2. M. Karrou, M. El Mourid, M. Boutfirass, M. El Gharous, Al Awamia 123-124 (2008)

3. ONICL. Cereal statistics, Office National Interprofessionnel des céréales et Légumineuses (2020). www.ONICL.org.ma 